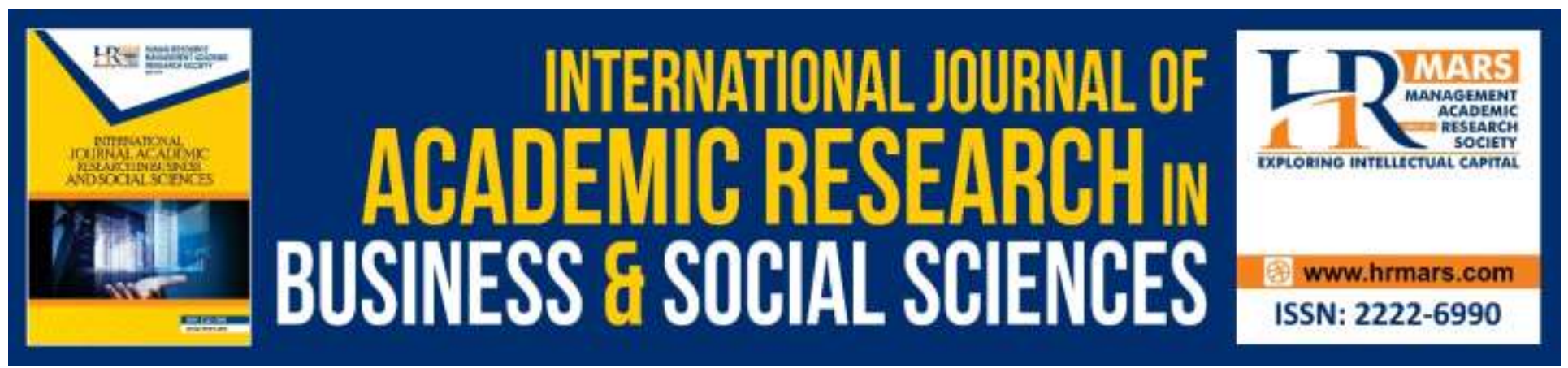

\title{
Entrepreneurship Competency Enhancement Training: a study among the Managers of Internet Centres
}

\author{
Mohd Nor Hakimin Yusoff, Mohammad Ismail, Hasannuddin Hassan and \\ Abdullah Al Mamum
}

To Link this Article: http://dx.doi.org/10.6007/IJARBSS/v9-i7/6112

DOI: $10.6007 /$ IJARBSS/v9-i7/6112

Received: 12 May 2019, Revised: 27 June 2019, Accepted: 07 July 2019

Published Online: 29 July 2019

In-Text Citation: (Yusoff, Ismail, Hassan, \& Mamum, 2019)

To Cite this Article: Yusoff, M. N. H., Ismail, M., Hassan, H., \& Mamum, A. Al. (2019). Entrepreneurship Competency Enhancement Training: a study among the Managers of Internet Centres. International Journal of Academic Research in Business and Social Sciences, 9(7), 233-245.

Copyright: (C) 2019 The Author(s)

Published by Human Resource Management Academic Research Society (www.hrmars.com)

This article is published under the Creative Commons Attribution (CC BY 4.0) license. Anyone may reproduce, distribute, translate and create derivative works of this article (for both commercial and non-commercial purposes), subject to full attribution to the original publication and authors. The full terms of this license may be seen

at: http://creativecommons.org/licences/by/4.0/legalcode

Vol. 9, No. 7, 2019, Pg. 233 - 245

http://hrmars.com/index.php/pages/detail/IJARBSS

JOURNAL HOMEPAGE

Full Terms \& Conditions of access and use can be found at http://hrmars.com/index.php/pages/detail/publication-ethics 


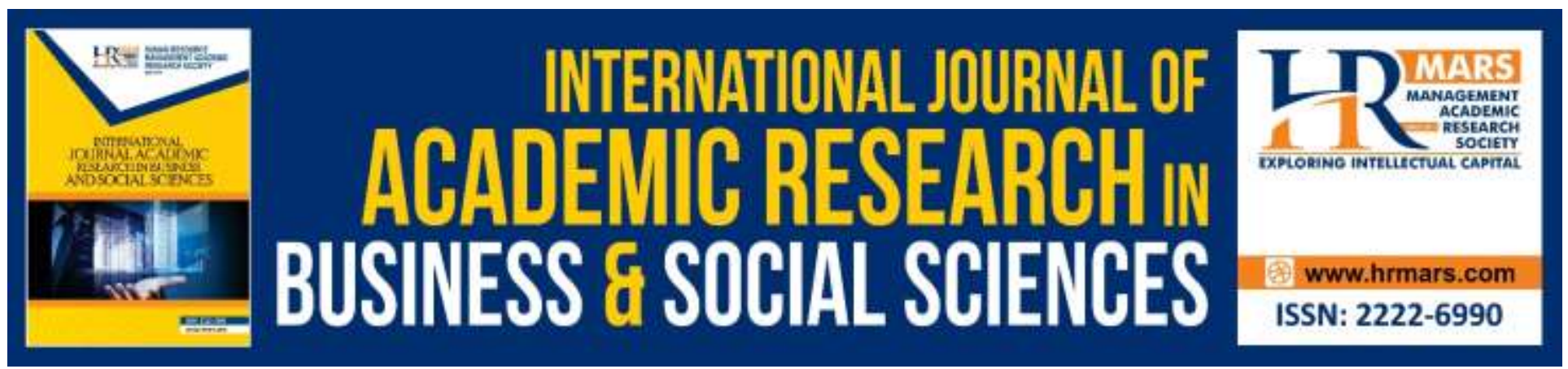

\title{
Entrepreneurship Competency Enhancement Training: a study among the Managers of Internet Centres
}

\author{
Mohd Nor Hakimin Yusoff ${ }^{1}$, Mohammad Ismail ${ }^{2}$, Hasannuddin \\ Hassan $^{3}$ and Abdullah Al Mamum ${ }^{4}$ \\ ${ }^{1}$ Associate Professor, Institute for Small Medium Enterprise (ISME), University Malaysia Kelantan, \\ Malaysia, ${ }^{2}$ Associate Professor, Centre of Enterpreneurship Education Development \\ ${ }^{3}$ Lecturer, Faculty of Entrepreneurship and Business, University Malaysia Kelantan, Malaysia \\ ${ }^{4}$ Research Fellow, Global Entrepreneurship Research and Innovation Centre (GERIC), UMK, Malaysia
}

Abstract: The objective of this study is to examine the effectivenss of the competency enhancing training program designed for the managers of Internet Centres. This study adopted a cross sectional design and quantitative data was collected from 26 participants, who attended the traing program. Findings of this study revealed that participant's level of knowledge on the topics of self-competency, identfying business opportunities, selecting form of business and setting setting up a business and managing small and medium enterprises have increased after participating the training module. This confirms the effectiveness of the training programs by Institute for Small Medium Enterprise which should be expended and included in future entrepreneurial training programs.

Keywords: Training Effectiveness, Competency, Skills, Opportunity Recognition

\section{Introduction}

Creating a knowledgeable and competent worker is becoming a great challenge in present business world. The demand for high skills workers is paramount important to deal with sofisticated customers and the dynamic business environment. Thus, the management of the orgnisations invested a huge amount of money in the training and development programmes for their workers. The aim is to enhance the workers' skills and capacity that finally would give favourable impact on the organisation's performance.

Training and development programs were seriously designed by most of the developed countries. Japanese business organizations for instances, believed that competitive human resources is one of the key success factors for the organizations. The notion brings to the development of well and organized structure of human resources training programs. The government of Malaysia shared the same thought when the training and development programs have been main focus in almost all of the 5 years Malaysian Plan. 
Previous studies indicated that the impact of the training programmes on the workers were mixed. Some studies revealed that the programmes has positive impact towards workers skills and capability to make decision (Asfaw, Argaw \& Bayissa, 2015; Tai, 2006). However, there were also a number of studies conducted showed the training programmes did not produce significant impact on the organisations performance (Lo, Mohamad \& La, 2009; Cunha et al., 2003) and some studies found that firm specific training programs do not have a positive impact on organization performance (Barrett \& O'Connell, 2001; Lynch \& Black, 1995).

On the other hand, training and development programs aimed at employees is linked increases their performance at workplace, it provides them with knowledge and enhances their skills. This creates an efficient and effective employee which leads to organizational performance (Kulkarni, 2013). Another study focusing on the banking industry found that training and development programs conducted by bank management increased the level of employee effectiveness and lead to higher level of competitive advantage and competitiveness (Falola, Osibanjo \& Ojo, 2014). Since a huge sum of money spent for training programs, an impact study is necessary to reveal the effectiveness of the programs. Therefore, this study was conducted to measure the effectiveness of the training programs conducted among Managers and Assistant Managers of 1Malaysia Internet Centre in Kelantan.

\section{Study Context: Overiew of the Training Program}

The Institute of Small and Medium Enterprises (ISME) Universiti Malaysia, Kelantan has been entrusted to provide training programs to the Manager and Assistant Manager of the Internet Centre (internet centre) for period of 2 years. The program is known as High Performance Entrepreneurs Development Program which involving 16 internet centres in Kelantan. The objectives of the training program is to develop entrepreneurial skills among the internet cnetres' staff. Beside that, the program also aimed to foster entrepreneurial knowledge in the field of information, communication and technology so that, its would upgrade participants' capacity and soft skills. The programs offered 3 modules in three different stages. Stage 1 is focusing on Entrepreneurship Training Programs. Stage 2 is on Sustainable Program and final stage is the Monitoring and Reporting. This present study is to access on the Stage 1 (Series 1 ) training programs only. In the Stage 1 (Series 1 ) training programs, participants were exposed to identification of self-competency assessment technique which allign to entrepreneurial competency including business opportunity identification techniques. Participants learnt about the process involve in selecting the best business opportunities. Furthermore, the module extend the participants knowledge on form of business, different form of business and legal issues. Participants are exposed to every form of legal implications under the laws and regulations that must be followed in setting up a business entity. Finally, participants learnt about managing small and medium enterprises (SMEs) and its related issues. Participants were also exposed to the characteristics and peculiarities of SMEs in Malaysia.

The opening of the internet centre is one of the government's strategy to increase broadband access in the country. The operation which was started in 2010 was focused on providing access to rural areas. However, beginning 2013, the government has taken bold steps by expanding the coverage of operation to urban poor areas with particular to the selected People's Housing Project (PHR). The 
establishment of the internet centres provides an opportunity for rural folks to take advantages on the state-of-the art technology in improving their social and economic status. It goes without saying that internet technology has given significant impact to the business and social activities. The government expected that with wide range of broadband access, it will reduces digital gap especially computer illiteracy among people. With increasing number of technology-skilled people it will contribute to the improvement of entrepreneurial activity within the community. Therefore, internet centre would act as a catalyst in realizing the government's aspiration to narrow down the digital gap and improve local entrepreneurship activities. To enable internet centres operates effectively, the staff must be equipped not only with the entrepreneurship skills and knowledge but also information, communication and technology skills. Skilled employees could effectively provide training and development to the community.

Thus, the General Manager and Assistant General Manager internet centers must duly equipped with the knowledge of entrepreneurship, basic ICT and soft skills so that the activities becomes meaningful to the communities. It is also important that the development of internet centre activities in parallel with the objective of promoting entrepreneurship in particular ICT-related activities within local communities.

\section{Literature Review}

Training program is a continous learning process developed to transform attitude, knowledge and skill of employees for improving work performance. The program is believed to give benefit to the organisation as well as employees. It is also believed that employees with sufficient knowledge and skills have better performance compare to who did not. Cheng and Ho (2001) posit that a training dan development program for employees is vital to upgrade employees' skills. The author further argued that the program plays important role in upgrading and sustaining skills. On the other hand, the development program is to enhance skills for future development of organisations.

On another development, Kapp (2002) and Noe (2002) argued that the training program not only a continuous learning process, but it is a well-planned agenda by the organization to upgrade employees' capacity and skills. In the modern organizational management, majority of employers spent a huge sum of money for training programs. A structured and scheduled training are provided which covers knowledge, skills and attitude, among others. The management's aimed to have high quality employees who then contribute to the betterment of the organizations. In the competitive and dynamic business environment, training program is an effective management tool to produce high quality human capital for sustainable business activities.

\section{Self-Competency}

Self-competency is regarded as how an individual sees or believes themselves as being skillful, competent and successful in achieving their goals (Dogan, 2011). Tafarodi \& Swann (1995) describe that humans view themselves as strong or weak rather than simply potive or negative with is referred as self-competence. It was further explained that self-competence is something internally, where we decide on what we want to achieve with our actions and looking and the results of our actions. It our 
actions and results match, and we take credit on it, it raises our self-competence level (Tafarodi \& Swann, 1995). Thus self-competence is regarded as a motivator when done right as believing one is competent, definitely it makes the person feel good. Under the Entrepreneurship Competency Enhancement Training, internet center managers were exposed to the aspects of competency recognition, competency recognition technique, exploiting personal competency, developing personal competency, application of personal competency and evaluating personal competency.

\section{Business Opportunity}

Opportunities plays an important role in the entrepreneurial phenomenon, this opportunities can only be utilized when the entrepreneur manage to recognize it and acknowledge it's important and value for their business (Shane \& Venkataraman, 2000). Research in the area of business opportunity recognition has been keen on finding why certain individuals manage to recognize opportunities while other does not. It was found that information (Shane \& Venkataraman, 2000) plays a major role in opportunity recognition and information such as changes in politic, economy, technology, social and demographic aspects are crucial in opportunity recognition (Baron, 2006). In the process of opportunity recognition, network ties, entrepreneurial alertness and prior knowledge are considered as antecedents ((Kontinen \& Ojala, 2011; Lim \& Xavier, 2015). An entrepreneur's social network is related to opportunity recognition as social ties provide the entrepreneur with information concerning new opportunities and it was discovered that dense social ties filled with informal industry network and mentors, the greater is the effect on opportunity recognition (Ozgen \& Baron, 2007). Alertness in the process of opportunity recognition is where an entrepreneur being more aware in the changes and ability to notice opportunities that have been overlooked without the act of searching (Kirzner, 1999). Prior knowledge is regarded important in the process of business opportunity recognition as the prior knowledge and life experiences make it possible for individuals to recognize opportunities (Lim \& Xavier, 2015). Increased knowledge leads to the possibility to absorb more information and with these information individuals would be able to make more efficient decisions, which results in better opportunity recognition.

Opportunity recognition is an important part in the entrepreneurial process as it expected to lead towards successful ventures (Lim \& Xavier, 2015). Ardichvili, Cardozo \& Ray (2003) found that successful opportunity recognition based on prior knowledge on market and customers lead to successful business. Opportunity recognition process involves active and passive search (Ardichvili, Cardozo \& Ray, 2003). In active search of opportunity, it involves searching for opportunities through personal contacts and public information sources while, passive search, individuals recognize opportunities by accident where they are receptive to opportunities, but not actively engaged in the search (Ardichvili, Cardozo \& Ray, 2003). Acknowledging the importance of business opportunity recognition to entrepreneurs, Entrepreneurship Competency Enhancement Training program conducted by The Institute for Small and Medium Enterprises included modules such as the need for opportunity identification, the importance of opportunity identification and the technique of opportunity identification. 
INTERNATIONAL JOURNAL OF ACADEMIC RESEARCH IN BUSINESS AND SOCIAL SCIENCES Vol. 9, No. 7, July, 2019, E-ISSN: 2222-6990 @ 2019 HRMARS

\section{Venture Formation}

Spinelli \& Adams (2009) expresses that the classical view of entrepreneurship is the raw start-up of company based on innovative idea that grows into high-growth venture. But in the modern and dynamic business world, venture formation requires an individual need to be equipped with skill and know-how ability to find and manage resources for venture success. The question about law and legal issues in the development of business venture have been discussed numerous time and tested, yet remain open because variability and variety of legal system and regulations of different countries and how they affect entrepreneurship worth given attention (Serafimovska \& Sotiroski, 2014). Law and regulations affect ventures in many forms, positively; it can encourage ventures by reducing entry barriers, guaranty enforcement and property rights protections, negatively; it can put on limitation by strict implementation and restrictive laws. In setting up a venture, individuals should consider the different form of business. Things to consider before deciding will be; government regulations; reporting requirement; level of responsibility; tax structure; skill needed to run the business; financing needs and liability exposure (Skripak, Parsons, Cortes \& Walz, 2016). Based on those factors, entrepreneurs can choose from the various types of business structure such as sole proprietorship, partnership, limited partnership, corporation, cooperatives and not-for-profit corporations. To equip managers of 1 Malaysia internet centres with needed knowledge regarding to venture formation, Entrepreneurship Competency Enhancement Training program conducted by The Institute for Small and Medium Enterprises included modules such as business law, the differences between form of business, legal issues and director's duty as part of the training.

\section{Business Management}

Business management is regarded as the act of managing firm resources such as human, materials, machine and money to achieve organizational goals (Dingee et al., 1995). Ghislain (2014) describes modern business management as a vulnerable force, under pressure to achieve outcomes and equipped with imagination, imitation and constraints. In order to carry out the scope of business management, the entrepreneurs need to have a certain level of skill and knowledge regarding business management. Dingee et al., (1995) have listed out seven core elements of skill or knowledge needed by individuals to perform effective management i.e. marketing and sales, operations management, research, development and engineering, financial management, general management and administration, personnel management, and legal and tax aspects. With the skill and management knowledge mentioned earlier, entrepreneurs would be able to know how to manage resources towards the organizational goals. Apart from that, entrepreneurs should pay attention to critical factors in determining venture success. Osterwalder \& Pigneur (2010), presented nine elements that is critical for venture viability which includes, value proposition, key partners, key business activities, key resources, customer relationship, customer segments, channels of distribution, cost structure and revenue streams. Besides personal factors of entrepreneurs and their skills and management knowledge, environmental factors such as political, social, economic, cultural and infrastructure have either positive or negative impact on entrepreneurial activities (Abimbola \& Agboola, 2011). Earlier study by Zapalska, Dabb \& Perry (2003), found that environmental factors such as financial support, non-financial assistance, entrepreneurial and business skills, cultural and ethnic conditions, and policies and procedures as important environmental factors affecting 
indigenous Maori entrepreneurs in New Zealand. Given the important of business management, critical factors and the role of environmental factors in business ventures, Entrepreneurship Competency Enhancement Training program conducted by ISME include modules such effective management, critical factors, environmental influences and effects of globalization as part of their training program.

An effective training programs positively changed employees' behavior and conduct in the organizations. Knowing the important of effective training programs, the management should also focus on after training supervision. After training supervision is aimed to evaluate the impact of the programs to the employees. Thus, this study aimed to measure the effectiveness of the training program by examining the impact to the managers' knowledge and skills.

\section{Methodology}

This study adopted a sectional design to examine the effectiveness of the competency enhancing training program designed for the managers of 1Malaysia Internet Centres. The study was conducted on 27 participants who attended the Stage 1 training module. 27 questionnaires were distributed which consists of 25 questions covering 4 demographic questions and 21 questions measuring the effectiveness by using a Likert scale of 1 to 5 (strongly disagree - strongly agree). Participants were asked to answer the survey questions before the training begin and after the training ends. By answering question at two different times allow participants to assess their level of knowledge on the training module. Before the training begin participants were asked to give their judgment on the knowledge of the topics to be discussed. Again, after-training- evaluation were conducted to assess participants' level of knowledge after completing the module. Of the 27 questionnaires distributed, 26 questions have been returned.

\section{Findings \& Discussions}

\section{Demographic Details}

As noted in Table 1, 53\% of participants are youth aged between 26 and 35 years. Out of that, 38\% are below 25 years and only $7 \%$ of those aged between 36 and 45 years old. In terms of gender, 70\% of participants were women. The majority of participants obtained first degree (76.9\%), $15.4 \%$ and $7.7 \%$ holds Diploma and SPM, respectively. Since the majority of the participants are young, $88.5 \%$ have less than 5 years of experience.

Table 1: Demographic

\begin{tabular}{lcclcc}
\hline Age & $\mathrm{N}$ & $\%$ & Education Level & $\mathrm{n}$ & $\%$ \\
$<25$ & 10 & $38.5 \%$ & SPM & 2 & $7.7 \%$ \\
$26-35$ & 14 & $53.8 \%$ & Diploma & 4 & $15.4 \%$ \\
$36-45$ & 2 & $7.7 \%$ & ljazah & 20 & $76.9 \%$ \\
& & & & & \\
Gender & 8 & $30.8 \%$ & Experience & & \\
Male & 18 & $69.2 \%$ & $<5$ tahun & & \\
Female & & & $6-10$ tahun & 1 & $3.8 \%$ \\
& & & $11-15$ tahun & 2 & $7.7 \%$ \\
\hline
\end{tabular}


INTERNATIONAL JOURNAL OF ACADEMIC RESEARCH IN BUSINESS AND SOCIAL SCIENCES

Vol. 9, No. 7, July, 2019, E-ISSN: 2222-6990 ¿ 2019 HRMARS

\section{Training Evaluation}

The evaluation score of knowledge about the contents of the module before and after training were discussed in this section. The discussion is divided into four subsections, namely (a) Self-Competency Assessment, (b) Evaluation on Identifying Business Opportunities Module, (c) Evaluation on Selecting Form of Business and Setting up a Business Module, and (d) Managing Small and Medium Enterprises Module

Self-Competency Assessment - Six items were used in measuring the effectiveness of the training module. Majority of participants' knowledge about the module low before the completing the module. The mean score is between 2.6 to 2.9. However, after the training, majority of participants marked at high score for all the six items measurement. Mean scores for this construct is between 4.15 to 4.46. The mean score and standard deviation for each measurement item on show in Table 2.

Table 2. Self-Competency Assessment

\begin{tabular}{|c|c|c|c|c|c|}
\hline & \multicolumn{3}{|r|}{ Before } & \multicolumn{2}{|c|}{ After } \\
\hline & \multirow[b]{2}{*}{$\mathrm{N}$} & \multicolumn{2}{|l|}{ Mea } & \multirow[b]{2}{*}{ Mean } & S. \\
\hline & & $\mathrm{n}$ & S. Deviation & & Deviation \\
\hline \multirow[t]{2}{*}{ Competency Recognition } & 26 & 2.76 & 0.992 & 4.269 & 0.533 \\
\hline & & 9 & & & \\
\hline \multirow[t]{2}{*}{ Competency Recognition Technique } & 26 & 2.80 & 0.849 & 4.462 & 0.582 \\
\hline & & 8 & & & \\
\hline \multirow[t]{2}{*}{ Exploiting Personal Competency } & 26 & 2.61 & 0.804 & 4.154 & 0.464 \\
\hline & & 5 & & & \\
\hline \multirow[t]{2}{*}{ Developing Personal Competency } & 26 & 2.76 & 0.765 & 4.385 & 0.571 \\
\hline & & 9 & & & \\
\hline \multirow[t]{2}{*}{ Application of Personal Competency } & 26 & 2.84 & 0.784 & 4.462 & 0.582 \\
\hline & & 6 & & & \\
\hline \multirow[t]{2}{*}{ Evaluating Personal Competency } & 26 & 2.96 & 0.774 & 4.308 & 0.549 \\
\hline & & 2 & & & \\
\hline
\end{tabular}

Business Opportunity - Three items were used to measure the level of knowledge of participants on identifying business opportunities module. Overall, before joining this module participants selfevaluation were 'low' on all three items of measurement. The mean scores for the three items were between 2.42 to 2.76. At the end of the training, all participants recorded high score which indicated the increasing level of knowledge on the module. This is shown by the mean score for each item ranges between 4.19 to 4.43 . 
INTERNATIONAL JOURNAL OF ACADEMIC RESEARCH IN BUSINESS AND SOCIAL SCIENCES Vol. 9, No. 7, July, 2019, E-ISSN: 2222-6990 @ 2019 HRMARS

Table 3. Business Opportunity

\begin{tabular}{|c|c|c|c|c|c|}
\hline & \multirow[b]{3}{*}{$\mathrm{N}$} & \multicolumn{2}{|c|}{ Before } & \multicolumn{2}{|c|}{ After } \\
\hline & & Mea & \multirow{2}{*}{$\begin{array}{c}\text { S. } \\
\text { Deviation }\end{array}$} & \multirow[b]{2}{*}{ Mean } & \multirow{2}{*}{$\begin{array}{c}\text { S. } \\
\text { Deviation }\end{array}$} \\
\hline & & $\mathrm{n}$ & & & \\
\hline \multirow[t]{2}{*}{ The need for opportunity identification } & 2 & 2.46 & 0.948 & 4.269 & 0.604 \\
\hline & 6 & 2 & & & \\
\hline \multirow{4}{*}{$\begin{array}{l}\text { The importance of opportunity } \\
\text { identification } \\
\text { The technique of opportunity identification }\end{array}$} & 2 & 2.76 & 0.992 & 4.346 & 0.629 \\
\hline & 6 & 9 & & & \\
\hline & 2 & 2.42 & 0.857 & 4.192 & 0.491 \\
\hline & 6 & 3 & & & \\
\hline
\end{tabular}

Table 4. Venture Formation

\begin{tabular}{|c|c|c|c|c|c|}
\hline & \multicolumn{3}{|r|}{ Before } & \multicolumn{2}{|c|}{ After } \\
\hline & \multirow[b]{2}{*}{$\mathrm{N}$} & \multicolumn{2}{|l|}{ Mea } & \multirow[b]{2}{*}{ Mean } & S. \\
\hline & & $\mathrm{n}$ & S. Deviation & & Deviation \\
\hline \multirow[t]{2}{*}{ Business Law } & 26 & 2.23 & 0.908 & 4.077 & 0.484 \\
\hline & & 1 & & & \\
\hline \multirow{2}{*}{$\begin{array}{l}\text { The differences between form of } \\
\text { business }\end{array}$} & 26 & 2.19 & 0.749 & 4.269 & 0.533 \\
\hline & & 2 & & & \\
\hline \multirow[t]{2}{*}{ Legal issues } & 26 & 2.11 & 0.909 & 4.538 & 0.855 \\
\hline & & 5 & & & \\
\hline \multirow[t]{2}{*}{ Director's duty } & 26 & 2.11 & 0.909 & 4.192 & 0.634 \\
\hline & & 5 & & & \\
\hline
\end{tabular}

Venture Formation - To measure the level of knowledge and understanding of participants about the selection procedures and the establishment of a business firm, four measurement items used. Knowledge and understanding are measured from a legal perspective, the differences between the business implications and lawsuits as well as the responsibility of the owner / director of the company. Before joining this module participants create a self-assessment of knowledge and understanding of elections and the establishment of an approaching score 'very low'. This can be seen from the mean score of the lowest and the highest 2.115 2.231, as noted in Table 4. However, this score changed after participants have completed this module spending. Scores for all four measurement items increased to 4.077 to 4.538 .

Business Management - Four items were used to measure the effectiveness of the Company's Management modules to participants. Measurement items include knowledge of effective management, critical success factors, and the impact of globalization perserkitaran effect on the business. Scores before training module shows knowledge 'low'. The mean score between 2.192 to 2.808. Walaubabagaimanapun, participants gave higher scores after undergoing this module. Mean 
INTERNATIONAL JOURNAL OF ACADEMIC RESEARCH IN BUSINESS AND SOCIAL SCIENCES Vol. 9, No. 7, July, 2019, E-ISSN: 2222-6990 @ 2019 HRMARS

score after undergoing this module is improved to 4.192 to 4.500 indicating a higher level of understanding among the managers of 1Malaysia Internet Centres.

Table 5. Business Management

\begin{tabular}{|c|c|c|c|c|c|}
\hline & \multicolumn{3}{|r|}{ Before } & \multicolumn{2}{|c|}{ After } \\
\hline & \multirow[b]{2}{*}{$\mathrm{N}$} & Mea & & & S. \\
\hline & & $\mathrm{n}$ & S. Deviation & Mean & Deviation \\
\hline \multirow[t]{2}{*}{ Effective Management } & 26 & 2.19 & 0.634 & 4.192 & 0.634 \\
\hline & & 2 & & & \\
\hline \multirow{2}{*}{ Critical Factors } & 26 & 2.69 & 1.955 & 4.231 & 0.587 \\
\hline & & 2 & & & \\
\hline \multirow[t]{2}{*}{ Environmental Influences } & 26 & 2.80 & 0.895 & 4.500 & 0.510 \\
\hline & & 8 & & & \\
\hline \multirow[t]{2}{*}{ Effects of Globalization } & 26 & 2.53 & 0.989 & 4.423 & 0.578 \\
\hline & & 8 & & & \\
\hline
\end{tabular}

Overall participants gave a high score on the effectiveness of the modules offered courses. This indicates that the module is prepared for this program very relevant and have a positive impact on the knowledge and skills of the participants. The mean score is between 4.231 to 4.500 with a small standard deviation clearly shows that the majority of participants strongly agreed with the effectiveness of modules offered.

Table 6. Overall Program Evaluation

\begin{tabular}{lccc}
\hline & & & $\begin{array}{c}\text { S. } \\
\text { Deviation }\end{array}$ \\
\hline & $\mathrm{N}$ & Mean & 0.587 \\
Personal Competency Module & 26 & 4.231 & 0.604 \\
Business Opportunity Recognition Module & 26 & 4.269 & 0.647 \\
Venture Formation Module & 26 & 4.462 & 0.648 \\
Business Management Module & 26 & 4.500 & 0.629 \\
\hline
\end{tabular}

Overall, participants gave a high score on the effectiveness of the modules offered. This indicates that the modules are pertinent and give a positive impact on the development of knowledge and skills of the participants. With the added knowledge in the field of entrepreneurship and business, the training program for local community will be more effective. In addition, skillful and knowledgeable workers have broader perspective on entrepreneurial activities. They would be able to identify a lot of business opportunities that could be carried out internet centre area. This activities provide a platform to raise awareness and propensity to venture into business among local community..

Moreover, the participants can play a more effective role in encouraging community members to venture into entrepreneurial activity and exploit ICT as enabler in line with national agenda. 
INTERNATIONAL JOURNAL OF ACADEMIC RESEARCH IN BUSINESS AND SOCIAL SCIENCES Vol. 9, No. 7, July, 2019, E-ISSN: 2222-6990 @ 2019 HRMARS

Indirectly, the programs become a catalyst to internet centres in realizing their objectives of reducing the digital gap among rural communities and increase the number of rural entrepreneurs at the same. In short, high skills and knowledge managers could effectively contribute to the development of rural area.

\section{Conclusion}

High-Performance Entrepreneur Development Program Phase I has been running successfully and a total of 4 modules have been carried out and received positive feedbacks from the participants. For the Stage I modules, it emphasised on the basic skills that should be possessed by entrepreneurs and potential entrepreneurs. Stage I of the training program included modules of Personel Competency, Business Opportunity Recognition, Venture Formation and Business Management. It was found that the level of knowledge among participant in the said area were measured and once again the level of knowledge were measured at the end of training program. It was found that, level of knowledge in the subjects of competency, opportunity recognition, venture formation, business management and its components increased.

It can be concluded that, the module introduced, gave positive impact on the level of knowledge and skills of the participants, and achieved the objective of developing entrepreneurial skills among the internet centre's staff. Future training programs aiming to equip entrepreneurs, potential entrepreneurs and managers of small and medium firms, should include the modules produced by High-Performance Entrepreneur Development Program under The Institute for Small and Medium Enterprises as knowledge, skill and training is important in the entrepreneurial process and venture success.

Acknowledgements: This paper is based on training program conducted for Nera Infocom (M) Sdn Bhd with support from Maxis and Malaysian Communications and Multimedia Commissions. This publication reflects the views of the authors, and the parties cannot be held responsible for any use which may be made of the information contained herein.

\section{Reference}

Abimbola, O. \& Agboola, G. (2011). Environmental Factors and Entrepreneurship Development in Nigeria. Journal of Sustainable Development in Africa, 13(4), 166-176.

Ardichvili, A., Cardozo, R., \& Ray, S. (2003). A theory of entrepreneurial opportunity identification and development. Journal of Business Venturing, 18(1), 105-123.

Asfaw, A., Argaw, M., \& Bayissa, L. (2015). The Impact of Training and Development on Employee Performance and Effectiveness: A Case Study of District Five Administration Office, Bole Sub-City, Addis Ababa, Ethiopia. Journal of Human Resource and Sustainability Studies, 03(04), 188-202.

Baron, R. (2006). Opportunity Recognition as Pattern Recognition: How Entrepreneurs "Connect the Dots" to Identify New Business Opportunities. Academy Of Management Perspectives, 20(1), 104-119.

Barrett, A. \& O'Connell, P. (2001). Does Training Generally Work? The Returns to in-Company Training. ILR Review, 54(3), 647-662. 
INTERNATIONAL JOURNAL OF ACADEMIC RESEARCH IN BUSINESS AND SOCIAL SCIENCES

Vol. 9, No. 7, July, 2019, E-ISSN: 2222-6990 @ 2019 HRMARS

Cheng, E. \& Ho, D. (2001). The influence of job and career attitudes on learning motivation and transfer. Career Development International, 6(1), 20-28.

Cunha, R., Cunha, M., Morgado, A., \& Brewster, C. (2003). Market Forces, Strategic Management, HRM Practices and Organizational Performance, a Model Based in European Sample. Management Research, 1(1), 79-91.

Dingee, Alexander L. M., Brian Haslett, Leonard E. Smollen. (1995). “Characteristics of a Successful Entrepreneurial Management Team" Pratts Guide to Venture Capital Sources, Securities Data Publishing, Inc., NY, NY, , pp. 23-28.

Dogan, T. (2011). Two-Dimensional Self-Esteem: Adaptation of the Self-Liking/Self- Competence Scale into Turkish: A Validity and Reliability Study. Education and Science, 36(162), 126-137.

Falola, H., Osibanjo, A., \& Ojo, S. (2014). Effectiveness of Training and Development on Employees' Performance and Organization Competitiveness in the Nigerian Banking Industry. Bulletin of the Transilvania University of Braşov Series V: Economic Sciences, 7(56), 161-170.

Ghislain, D. (2014). Management in xenophon's philosophy: A retrospective analysis. 38th Annual Research Conference. Chicago.

Kapp K. M. \& McKeague C. (2002). Blended Learning for Compliance Training Success, EduNeering, Princeton, New Jersey.

Kirzner, I. (1999). Creativity and/or Alertness: A Reconsideration of the Schumpeterian Entrepreneur. Review of Austrian Economics, 11, 5-17.

Kontinen, T. \& Ojala, A. (2011). International Opportunity Recognition among Small and MediumSized Family Firms. Journal of Small Business Management, 49(3), 490-514.

Kulkarni, P. (2013). A Literature Review on Training \& Development and Quality of Work LIfe. Journal of Arts, Science \& Commerce, 4(2), 136-143.

Lim, W. \& Xavier, S. (2015). Opportunity Recognition Framework: Exploring the Technology Entrepreneurs. American Journal of Economics, 5(2), 105-111.

Lo, M., Mohamad, A., \& La, M. (2009). The Relationship between Human Resource Management and Firm Performance in Malaysia. International Journal of Economics and Finance, 1(1). 103-109

Lynch, L. M., \& Black, S. E. (1995). Beyond the incidence of training: Evidence from a national employers' survey. NBER working paper 5231. Cambridge, Mass.

Noe, R. (2002), Employee Training and Development (2nd ed.), New York: McGraw-Hill.

Osterwalder, A. \& Pigneur, Y. (2010). Business model generation: a handbook for visionaries, game changers, and challengers (1st ed.). Hoboken NJ: Wiley.

Ozgen, E. \& Baron, R. (2007). Social sources of information in opportunity recognition: Effects of mentors, industry networks, and professional forums. Journal of Business Venturing, 22(2), 174192. Serafimovska, H. \& Sotiroski, L. (2014). Implications of the Legal Framework for the Development of Entrepreneurship. International Review Of Social Sciences And Humanities, 7(1), 263-273.

Shane, S. \& Venkataraman, S. (2000). The Promise of Entrepreneurship As A Field of Research. Academy of Management Review, 25(1), 217-226.

Skripak, S., Parsons, R., Cortes, A., \& Walz, A. (2016). Fundamentals of Business. Blacksburg: Pamplin College of Business. 
Spinelli, S. \& Adams, R. (2009). New venture creation: Entrepreneurship for the 21st century (8th ed.). Boston: McGraw-Hill Education.

Tafarodi, R. \& Swann, W. (1995). Self-Linking and Self-Competence as Dimensions of Global SelfEsteem: Initial Validation of a Measure. Journal of Personality Assessment, 65(2), 322-342.

Tai, W. (2006). Effects of training framing, general self-efficacy and training motivation on trainees' training effectiveness. Personnel Review, 35(1), 51-65.

Zapalska, A., Dabb, H., \& Perry, G. (2003). Environmental Factors Affecting Entrepreneurial Activities: Indigenous Maori Entrepreneurs of New Zealand. Asia Pacific Business Review, 10(2), 160-177. 